\title{
Enzo Di Natali, Bioetica e Magistero. Da Pio XII a Papa Francesco, Edizioni Medinova, Favara 2015, ss. 944.
}

Jedną z rozwijających się dynamicznie dyscyplin wiedzy współczesnej jest niewątpliwie bioetyka, która w sposób interdyscyplinarny próbuje ująć najważniejsze pytania etyczne dotyczące życia ludzkiego w jego fazie prenatalnej, w pełni życia, a także u jego schyłku. Rodziła się już ona w latach 60. XX w. w kontekście wielu postępów w dziedzinie medycyny, biomedycyny i biochemii, zaś ważny wpływ na jej ukształtowanie miał amerykański onkolog Van Rensselaer Potter (1911-2001), który w jednym z artykułów po raz pierwszy użył terminu „bioetyka” jako ,globalna ekologia życia”. Przez ostatnie pół wieku ukształtowało się wiele różnych paradygmatów bioetyki, które niektórzy autorzy sprowadzają do dwóch głównych: bioetyka jakości życia oraz bioetyka świętości życia ludzkiego.

Niezwykle ważnym głosem w dziedzinie bioetyki świętości życia ludzkiego jest nauczanie Kościoła katolickiego, który w oparciu o znane i tłumaczone od wieków kategorie filozoficzne i teologiczne, jak np. godność osoby, nienaruszalność życia ludzkiego, solidarność, podejmuje także kwestie bioetyczne. W tym kontekście warto wskazać opracowanie Barbary Chyrowicz z Katolickiego Uniwersytetu Lubelskiego Jana Pawła II Bioetyka. Anatomia sporu, w którym opisała szczegółowo zmagania o tożsamość bioetyki w jej różnych wymiarach.

Dogłębna analiza dokumentów i przemówień papieży przełomu XX i XX w. doprowadziła włoskiego badacza Enzo Di Natalego zaowocowała wydaniem monumentalnej, liczącej blisko 950 stron publikacji: Bioetica e Magistero. Da Pio XII a Papa Francesco [Bioetyka i Magisterium. Od Piusa XII do Franciszka]. Jest ona owocem ponad dziesięciu lat badań autora, prowadzonych na początku przy współpracy grupy studentów i wykładowców Papieskiego Ateneum Regina Apostolorum w Rzymie, zmotywowanych przez Gonzalo Mirandę, dziekana Wydziału Bioetyki tej uczelni. Okazuje się, że nawet w dobie internetu i dostępności niemal na wyciągnięcie ręki różnych źródeł, ich publikowanie w formie zwartych opracowań jest ciągle ważne i oczekiwane przez badaczy.

Całość problematyki bioetycznej została podzielona na piętnaście rozdziałów: prokreacja i małżeństwo, sztuczne zapłodnienie (homologiczne, heterologiczne, surogactwo), embriony, diagnostyka prenatalna, aborcja, klonowanie człowieka, sterylizacja, eksperymenty i badania, transplantacja organów, stosowanie środków 
przeciwbólowych, eutanazja i uporczywa terapia, respekt dla godności osoby. Przedstawienie tych treści i analiza tematyczna dokumentów Kościoła katolickiego zostały ukazane w kolejności chronologicznej, aby w ten sposób zaprezentować rozwój nauczania. Ponadto każdy z tematów został poprzedzony zwięzłym wprowadzeniem z punktu widzenia medyczno-naukowego, zaś dla lepszego ujęcia problematyki w treści cytowanych dokumentów Magisterium Kościoła katolickiego istotne sformułowania zaznaczono pogrubioną czcionką. W zakończeniu zaś do każdego z argumentów przedstawiony został krótki wykład zawartości danego tematu. Bardzo cennym dodatkiem jest także dość szczegółowa bibliografia do każdego z piętnastu tematów, podzielona za każdym razem na dwie grupy publikacji: $z$ nauczania Kościoła katolickiego oraz literatury przedmiotu i adresów najważniejszych stron internetowych. We wprowadzeniu Autor zauważył, że niektóre dokumenty zostały zacytowane w wielu punktach tematycznych, z uwagi na ich podejmowaną w nich różnorodną tematykę.

Książka jest kopalnią wiedzy na temat rozwoju myśli bioetycznej na przełomie XX i XXI w. Niezwykle istotne wydaje się sięgnięcie przez autora do tekstów Piusa XII, który poruszał tematy związane z bioetyką zanim jeszcze narodziła się formalnie ta nauka. Słynne przemówienia papieża Pacellego do różnych lekarzy, pielęgniarek, farmaceutów, położnych, przedstawicieli innych zawodów sanitarnych były doskonałą okazją do poruszania niezwykle trudnych zagadnień ze styku medycyny i etyki. Dzięki swoim doradcom, a zwłaszcza z pomocą późniejszego kardynała Fiorenzo Angeliniego, papieskie teksty w tamtym czasie były świadectwem wysokiej kompetencji Kościoła w dziedzinie moralności. Niemal każdy z przywołanych piętnastu tematów książki otwierają zatem fragmenty tekstów papieża Piusa XII.

Bardzo ważne i cenne dla czytelników są wypunktowania najważniejszych myśli niemal każdego z cytowanych dokumentów, w których autor starał się zawrzeć istotę przesłania bioetycznego danego tekstu. Pozwala to na szybką orientację $\mathrm{w}$ tematyce, a jednocześnie lepsze zapamiętanie różnych powiązań. Tego typu podsumowania czynią tę książkę bardziej dostępną dla osób, które nie czują się specjalistami w bioetyce lub teologii, a chciałyby w swoich poszukiwaniach korzystać z dokumentów źródłowych.

W niezwykle krótkim zakończeniu Autor zauważył, że zebrane materiały źródłowe należy czytać w podwójnym kluczu hermeneutycznym, obejmującym $z$ jednej strony zaufanie do przeprowadzonych poszukiwań naukowych, z drugiej zaś okazanie szacunku do godności osoby ludzkiej, wokół której tak naprawdę skupia się całe nauczanie bioetyczne Kościoła katolickiego.

Warto podkreślić szeroką panoramę wybranych źródeł, w których zostały podjęte w ostatnich dziesięcioleciach zagadnienia dotyczące życia ludzkiego. 
Znalazły się wśród nich: encykliki, adhortacje, listy, orędzia i przemówienia papieży: Piusa XII, Jana XXIII, Pawła VI, Jana Pawła II, Benedykta XVI i Franciszka; fragmenty Katechizmu Kościoła katolickiego Jana Pawła II oraz Kompendium Katechizmu Kościoła katolickiego; dokumenty Soboru Watykańskiego II, dokumenty dykasterii watykańskich: Kongregacji Nauki Wiary, Papieskiej Rady ds. Rodziny, Papieskiej Rady ds. Duszpasterstwa Pracowników Służby Zdrowia, Papieskiej Akademii Pro Vita, Papieskiej Rady Iustitia et Pax, Papieskiej Rady Cor Unum; dokumenty zwyczajnych i nadzwyczajnych zgromadzeń Synodów Biskupów; dokumenty konferencji biskupów różnych krajów, m.in.: Włoch, Stanów Zjednoczonych Ameryki Północnej, Portugalii, Hiszpanii, Wielkiej Brytanii (Anglii, Walii i Szkocji), Szwajcarii, Francji, krajów skandynawskich, Niemiec, Brazylii, Kanady; wystąpienia niektórych kardynałów, reprezentujących Stolicę Apostolską na różnych zgromadzeniach o randze międzynarodowej. Publikacja pozwala zatem spojrzeć z wielu różnych punktów widzenia świata katolickiego na aktualne problemy bioetyczne.

Krótką przedmowę do dzieła sporządziła Paola Ricci Sindoni, włoska filozof, pracująca w ramach Narodowego Komitetu Bioetyki, a także jedna ze współtwórców stowarzyszenia Scienza \& Vita, zajmującego się od 2005 r. w Italii zagadnieniami bioetycznymi, publikującego serię Quaderni di Scienza \& Vita. Autorka zauważyła, że z książki Enzo Di Noto przebija jasny przekaz, łączący wszystkie dokumenty papieskie od Piusa XII do papieża Bergoglio: to specyficzne ujęcie człowieka, niezależnie od kondycji, w jakiej się on znajduje. Nawet jeśli język tych dokumentów zmieniał się przez lata, to zawsze próbowano ukazywać niezbywalną godność każdej osoby ludzkiej, od poczęcia aż do naturalnej śmierci. Paola Sindoni zauważyła także, że książka ta może być cenna zarówno dla wierzących, pragnących pogłębić swoją wiedzę w zakresie bioetyki, jaki i niewierzących

Autor tak szerokiego opracowania nie ustrzegł się jednak nielicznych błędów edytorskich, a nawet merytorycznych; np. na s. 370 papieska adhortacja Familiaris consortio z 1981 r. została mylnie nazwana „encykliką”. Należy jednak docenić ogromną pracę redakcyjną i mery toryczną w przygotowaniu i opracowaniu książki, która pozostanie ważnym punktem odniesienia dla poszukujących inspiracji i głosu Kościoła katolickiego w kwestiach bioetycznych. Można żywić nadzieję, że podobne opracowania będą także wydawane w języku polskim.

ks. dr Wojciech Kućko

Wydziat Studiów nad Rodzina - UKSW w Warszawie 